\title{
THE OSMOTIC CONCENTRATING ABILITY IN HEALTHY INFANTS AND CHILDREN
}

\author{
BY \\ E. POLÁČEK, J. VOCEL, L. NEUGEBAUEROVÁ, M. ŠEBKOVÁ, and E. VĚCHETOVÁ \\ with the technical co-operation of M. Křištan and B. Trousilová \\ From the Institute for Research in Child Development, Pediatric Faculty, Prague, \\ First and Second University, Children's Departments, Prague, Infant Home, \\ Prague-Krč, Children's Home, Kunratice, Czechoslovakia
}

(RECEIVED FOR PUBLICATION OCTOBER 16, 1964)

The concentrating ability of the kidney changes with age: after birth it increases (Smith, 1959), and in old age it falls (Lindeman, van Buren, and Raisz, 1960). The maximum osmolality during the newborn period is much lower than in adults (Heller, 1944; Smith, Yudkin, Young, Minkowski, and Cushman, 1949; Barnett and Vesterdal, 1953; Hansen and Smith, 1953; McCance and Widdowson, 1954; Calgagno and Rubin, 1960; Fisher, Pyle, Porter, Beard, and Panos, 1963). This smaller concentrating ability rapidly increases after birth, as shown by the significantly higher maximum osmolality of the urine in mature and some premature children in the second to fourth week of life (Pratt and Snyderman, 1953; Edelmann, Barnett, and Troupkou, 1960), and may reach $1,473 \mathrm{mOsm}$./l. at the age of 35 days (Pratt, Bienvenu, and Whyte, 1948), and 1,570 mOsm./l. at 73 days (Drescher, Barnett, and Troupkou, 1962). The osmolality of the urine of premature infants in the first month of life can be low (Calgagno, Rubin, and Weintraub, 1954), particularly in premature infants with a birth weight below 2,250 g. in comparison with that of mature infants of the same age (Vocel, Poláček, Neugebaurová, and Šebková, 1963). Results in a number of series of children investigated with various tests showed a tendency for maximum osmolality to increase after the second month of life (Winberg, 1959; Poláček and Polanská, 1962; Martínek, Janovský, and Stanincová, 1962) and even after the first year of life (Winberg, 1959; Poláček, 1962). The comparison of these data is difficult because the methods used to achieve increasing concentration of urine were diverse. For this reason it seemed desirable to investigate subjects from the early postnatal period up to adult life, using a single method. Since premature infants with a low birth weight react to fluid restriction with lower concentration of urine, and sometimes even by haemoconcentration and raised non-protein nitrogen (Vocel et al., 1963; Fisher et al., 1963), only those premature infants with a birth weight over 2,250 g. were included in the series.

\section{Material and Methods}

The following 212 children were included in the investigation: 32 newborn infants from the First University Obstetric Department, 13 premature infants with a birth weight above $2,250 \mathrm{~g}$. in the First University Children's Department in Prague, 79 toddlers from the Children's Home in Kunratice, and 57 pre-school and school children in the Educational Department of the First University Children's Department in Prague. Children affected with serious disease and convalescents after acute illness were excluded. The concentration test was carried out by giving the children dried milk dissolved in half the usual amount of water with sugar added, for 24 hours, in amounts corresponding to their usual calorie intake. The preparation of full-cream milk was used for older children and a half-cream milk in younger infants. The urine was collected at intervals of about three hours and stored in the refrigerator. The temperature of infants and young children was taken frequently. If it rose above $37 \cdot 5^{\circ} \mathrm{C}$. the experiment was stopped, but the result of this abbreviated test was also taken into the series. Osmolality was determined cryoscopically by a thermistor connected up to a Wheastone bridge. The accuracy of the method was repeatedly checked by determining the depression of the freezing point on the same sample by the Beckmann thermometer. The difference between two measurements did not exceed $1 \%$. Maximum osmolality was taken as the highest osmotic value attained in the urine samples. Unusually high osmolality was determined at least three times and the probability of the results confirmed by determining specific gravity and concentrations of $\mathrm{Na}, \mathrm{K}, \mathrm{Cl}$, and urea. 


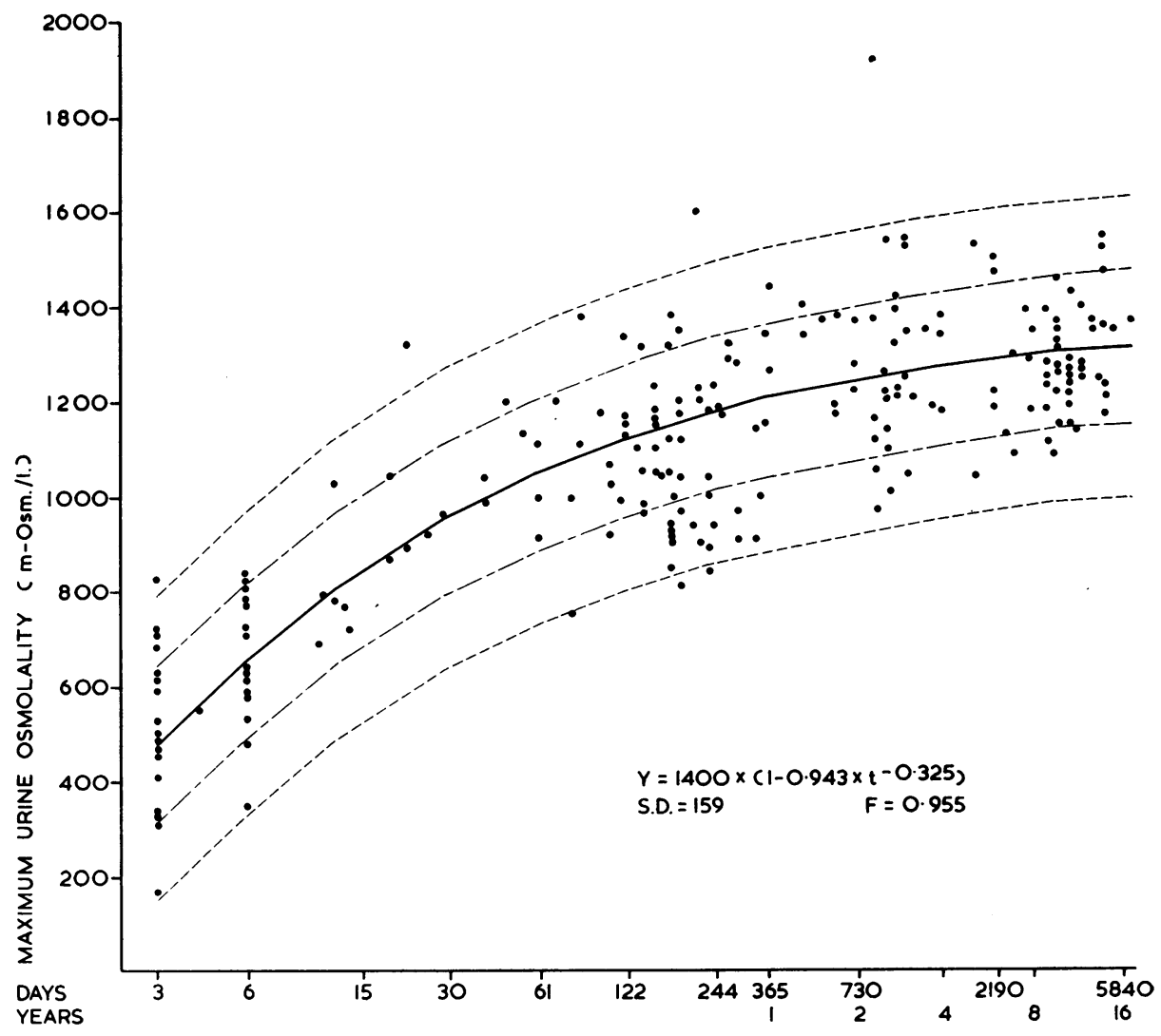

AGE (LOGARITHMIC SCALE)

FIG. 1.-Relation of maximum urine osmolality to age in healthy infants and children. Maximum urine osmolality of urine samples in course of 24-hour concentration test by means of double concentrated milk. Logarithmic scale for age.

TABLE 1

AVERAGE AND MAXIMUM URINE OSMOLALITY OF PREMATURE AND FULL-TERM INFANTS DURING FIRST WEEK OF LIFE

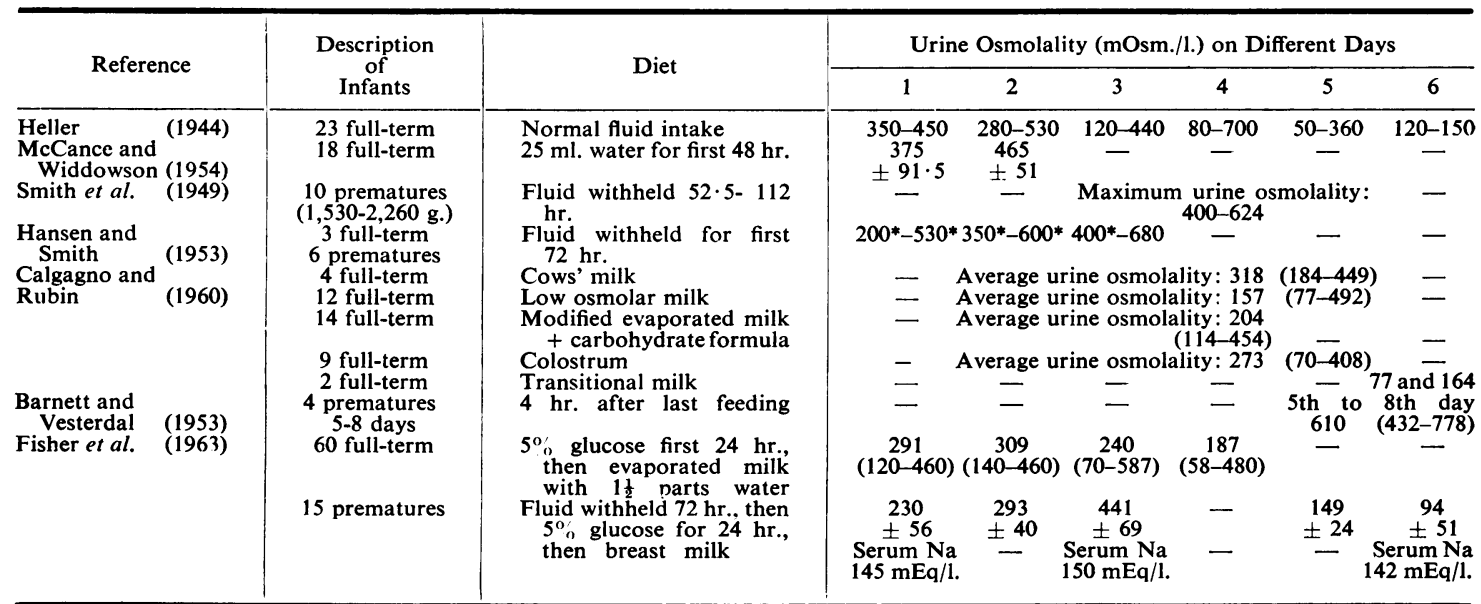

* Results given only in figures. Values estimated. 


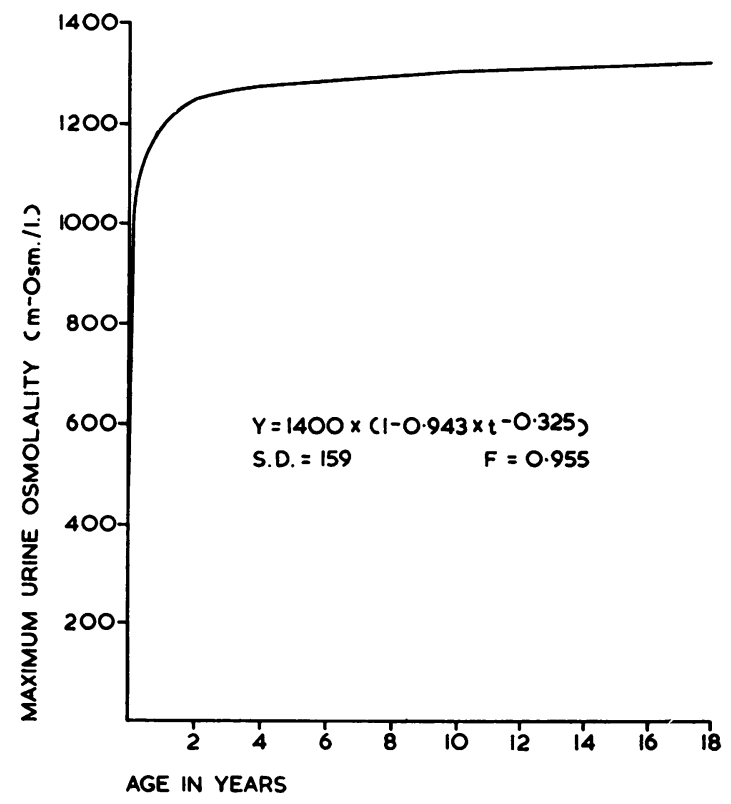

FIG. 2.- Regression line of maximum urine osmolality. Normal scale for age.

\section{Results}

The general results are given in Fig. 1 in which the age is expressed logarithmically, and it shows that the maximum osmolality of the urine tends to increase with age. However, the regression line does not run linearly $(F=1 \cdot 4 ; F(0 \cdot 05,200,500)=$ $1 \cdot 2)$, but exponentially $(F=0.955)$. The unconverted course of the regression line is given in Fig. 2, which shows that the average maximum osmolality of the urine increases rapidly in the first few months of life and that subsequently the rate of increase progressively slows down.

\section{Discussion}

All authors give much lower values for the osmolality of the urine in the first week of life than at a later age. In Table 1 are set out the results of a number of investigations on the concentrating ability of premature and full-term infants during the first week of life.

In our series the average maximum osmolality of the urine was $515 \mathrm{mOsm}$./1. (S.D. 172, $\mathrm{n}=17$ ) on the 3rd day, which is in good accord with findings of Hansen and Smith (1953) who found values of 400$680 \mathrm{mOsm} . / 1$. in 3-day-old infants without fluid intake.

In our series the average maximum osmolality on the 6 th day was $663 \mathrm{mOsm} . / 1$. (S.D. 133, $\mathrm{n}=16$ ), which is significantly higher than on the third day $(p<0.01)$ and corresponds approximately to values found by Barnett and Vesterdal (1953) in premature infants aged 5-8 days (432-778 mOsm./1.), but much higher than those quoted by Heller (1944) (on the 6th day 120-150 mOsm./1.) and by Fisher et al. (1963) (on the 6 th day 94 mOsm./l. \pm 51 ). These considerable differences in the results can be explained by the fact that in the last two groups the infants were given a small osmotic load with adequate fluid intake. Great diversity in the osmolality of the urine has been recorded from the end of the first week to the end of the first year. For this reason comparison should be restricted to investigations in which an increased osmotic load or a restriction of fluid intake has been employed or a combination of both. In Table 2 are set out the results of investigations in infants aged over 1 week up to 3 months.

We found that at the age of 10-30 days maximum osmolality of the urine amounted to an average value of 896 mOsm./l. (S.D. 179, $n=12$ ). This value is significantly higher than the average maximum osmolality in this series at 6 days $(p<0.001)$. This corresponds to the osmolality of the urine reached by infants of Edelmann et al. (1960) fed on 8-9 g. protein $/ \mathrm{kg}$.

The maximum osmolality noted in our infants aged 1-2 months reached an average of 1,054 mOsm./1. and is in agreement with the average osmolality in the infants of Pratt et al. (1948) after the first 24 hours of water restriction.

The osmolar concentrating ability of infants aged over 2 months was investigated by Winberg (1959). He first gave an intramuscular injection of pitressin tannate in oil $(0.5$ pressure units per $6 \mathrm{~kg}$. body weight) and then deprived the infants of all fluid for 16 hours by leaving out one or two feeds. The regression line in Winberg's series rose up to 1 to $1 \frac{1}{2}$ years. In children older than 3 years, Winberg recorded an average maximum osmolality of the urine of 1,069 mOsm./1. (S.D. 127, $\mathrm{n}=16$ ). Increase in urine osmolality with age in infants on a decreased fluid intake was noted by Martínek et al. (1962, Table 2).

In our series the regression line rises throughout the entire first year of life. In the children aged 1012 months maximum urine osmolality reached an average of 1,118 (S.D. 154, $\mathrm{n}=7$ ) and was significantly higher than in infants aged $2-5$ weeks $(p<$ $0 \cdot 02$ ). The increase in the regression line persists, though more slowly after the first year of life. At 14-18 years the average osmolality of the urine reaches 1,362 (S.D. 109, $n=9$ ), which is significantly higher than at the end of the first year $(p<0.01)$. It is very probable that some children in our series 
TABLE 2

MAXIMUM URINE OSMOLALITY OF INFANTS AGED 1 WEEK TO 3 MONTHS: RESULTS OF INVESTIGATIONS BY VARIOUS METHODS OF CONCENTRATION

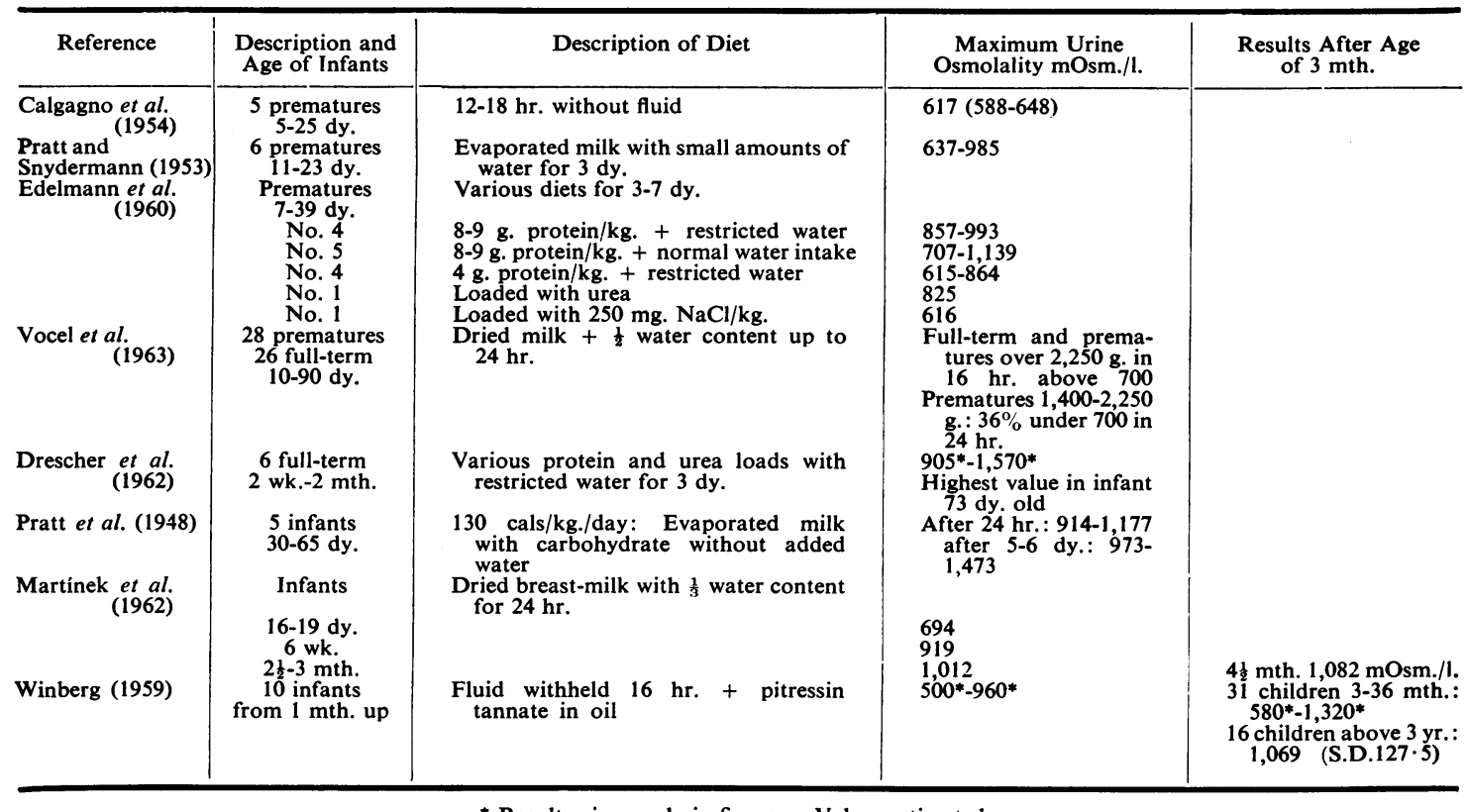

* Results given only in figures. Values estimated.

did not reach their maximum concentrating ability in the course of 24 hours. Others perhaps did not need to reach this limiting concentration. The results of Pratt et al. (1948), Drescher et al. (1962), and Sargent and Johnson (1954, 1956) furnish evidence that some children and young men can attain higher concentrations of the urine by more prolonged water restriction combined with adequate osmotic loading. Our experience (Poláček and Polanská, 1962) shows, however, that some healthy infants do not tolerate this prolonged water restriction without greatly increased temperature and other disturbances. The method described in this paper permitted the investigation of children in the same manner from the neonatal period up to puberty while sufficiently high values of urine osmolality were obtained.

\section{Summary}

A concentrating test was carried out in 212 children aged from 3 days to 18 years by giving them dried milk made up with half amount of water for 24 hours with addition of sugar and limited to the usual intake of calories. Urine was collected at three-hour intervals, and maximum osmolality of the urine was taken as the highest value found in the separate urine samples. This maximum urine osmolality increases with age from birth to puberty.
The average maximum urine osmolality values increase rapidly in the first months of life and then the increase is slower. There are significant differences between the average values of maximum urine osmolality on the $3 \mathrm{rd}$ day $(515 \mathrm{mOsm} . / 1$.$) , the 6$ th day $(663 \mathrm{mOsm} . / \mathrm{l}$.), the first month excluding the first week ( $896 \mathrm{mOsm} . / \mathrm{l}$.$) , the end of the first year$ $(1,118 \mathrm{mOsm} . / 1$. at $10-12$ months), and at puberty (1,362 mOsm./l. at 14-18 years). The regression line has an exponential character $(Y=1,400 \times(1-$ $\left.0.943 \times \mathrm{t}^{-0.325}\right)$ ).

\section{REFERENCES}

Barnett, H. L., and Vesterdal, J. (1953). The physiologic and clinical significance of immaturity of kidney function in young infants. J. Pediat., 42, 99.

Calgagno, P. L., and Rubin, M. I. (1960). Water requirements for renal excretion in full-term newborn infants and premature infants fed a variety of formulas. ibid., 56, 717 .

- - - and Weintraub, D. H. (1954). Studies on the renal concentrating and diluting mechanisms in the premature infant. J. clin. Invest., 33, 91.

Drescher, A. N., Barnett, H. L., and Troupkou, V. (1962). Water balance in infants during water deprivation. Amer.J. Dis. Child., $104,366$.

Edelmann, C. M., Jr., Barnett, H. L., and Troupkou, V. (1960) Renal concentrating mechanisms in newborn infants. J. clin. Invest., 39, 1062.

Fisher, D. A., Pyle, H. R., Jr., Porter, J. C., Beard, A. G., and Panos, T. C. (1963). Control of water balance in the newborn. Amer. J. Dis. Child., 106, 137.

Hansen, J. D. L., and Smith, C. A. (1953). Effects of withholding fluid in the immediate postnatal period. Pediatrics, 12, 99. 
Heller, H. (1944). The renal function of newborn infants. J. Physiol. (Lond.), 102, 429.

Lindeman, R. D., van Buren, H. C., and Raisz, L. G. (1960). Osmolar renal concentrating ability in healthy young men and hospitalized patients without renal disease. New Engl. J. Med., 262, 1306.

Martínek, J., Janovský, M., and Stanincová, V. (1962). Regulace hospodaření vodou a elektrolyty za dehydratace u kojencú. Cs. Fysiol., 11, 459.

McCance, R. A., and Widdowson, E. M. (1954). Normal renal function in the first two days of life. Arch. Dis. Childh., 29, 488.

Polácek, E. (1962). Vývoj koncentračni schopnosti ledvin. 100 let. St. zdrav. nakl. Praha. p. 257

and Polanská, M. (1962). Koncentrační pokus u kojencú. Cs. Pediat., 17, 1.

Pratt, E. L., Bienvenu, B., and Whyte, M. M. (1948). Concentration of urine solutes by young infants. Pediatrics, $1,181$.

-, and Snyderman, S. E. (1953). Renal water requirement of infants fed evaporated milk with and without added carbohydrate. ibid., 11, 65.
Sargent, F., II, and Johnson, R. E. (1954). Solute load and the renal osmotic parameters of chronically dehydrated men. J. clin. Invest., 33, 962.

- , and - (1956). The effects of diet on renal function in healthy men. Amer. J. clin. Nutr., 4, 466.

Smith, C. A. (1959). The Physiology of the Newborn Infant, 3rd ed., p. 331. Blackwell, Oxford.

Yudkin, S., Young, W., Minkowski, A., and Cushman, M. (1949). Adjustment of electrolytes and water following premature birth. Pediatrics, 3, 34.

Vocel, J., Polácek, E., Neugebaurová, L., and Šebková, J. (1963). Koncentrační test u nedonošencú a mladých kojencú. Cs. Pediat., 18, 774.

Winberg, J. (1959). Determination of renal concentration capacity in infants and children without renal disease. Acta paediat. (Uppsala), 48, 318. 